\title{
ANALISIS MUTU LAYANAN UNIT REKAM MEDIS BERDASARKAN KEPUASAN PELANGGAN INTERNAL DENGAN MENGGUNAKAN METODE SERVICE QUALITY DAN QUALITY FUNCTION DEPLOYMENT DI RSD KALISAT JEMBER
}

\author{
Ayu Widya Arizona ${ }^{1)}$, Nugroho Setyo Wibowo' ${ }^{2}$, Dian Damayanti ${ }^{3)}$ \\ Program Studi Rekam Medik, Jurusan Kesehatan Politeknik Negeri Jember \\ ayuwidyaarizona@yahoo.com ${ }^{1)}$, nugie.informatics@gmail.com ${ }^{2)}$,dr_dianadimulya@yahoo.co.id ${ }^{3)}$
}

\begin{abstract}
URM (Unit Rekam Medis) is one the healthy facilities headed by medical record chief. The head of medical record has the authority to manage everything related to URM. RSD Kalisat is one of state hospitals in Jember which has a vision as the pioneer hospital with the best quality and reachable for everyone. The quality of URM plays important role to support the quality of the hospital. One of the ways to measure the quality of URM is by using quality and quality function deployment method. This research is aimed to get the information about the quality service of medical record based on internal patient satisfactory in medical record at RSD kalisat by using quality and Quality Function Deployment (QFD). From the result of the analysis, we have conclusion as the following; 1) There are some variables influence the quality service of five dimension, such as: the strategic place of URM building from the ambulatory care, the strategic place of URM building from the long term care, thestorage room of medical record equipment, the number of employments, communication service, the rapidity of medical record file, the accuracy of medical record, the appropriateness of the information, medical record employee readiness, the accuracy of taking off the medical record file, the employee friendliness, the safety of medical record, the attitude of the employee dealing with the nurse. 2) The satisfactory of nuse toward to URM service is good enuogh. 3) The expecatation of "communication" with high score 4,60 and the expectation of "the distance between URM building from ambulatory care" with the lowest 4,26. 4) The priority related to nurse necessary needed to focus by URM dealing with medical record employee readiness which has normalize raw weight value 0,0588. 5) The action priority for URM employee is "internal and external training" which has the higher normalized contribution normalized contribution value0,2144
\end{abstract}

Keywords: Quality, Quality Service, Quality Function Deployment, Medical Record

\section{PENDAHULUAN}

RumahSakit Daerah (RSD) Kalisa ttermasuk salah satu rumahsakit yang bersaing dalam memberikan layanan terbaik bagi konsumen kesehatan. Namun untuk menjadi yang terbaik RSD Kalisat harus mampu menyediakan layanan minimal untuk meningkatkan kualitas layanan dan fasilitas yang diberikan kepada pelanggan. Layanan rekam medis adalah salah satu layanan minimal yang wajib disediakan oleh rumah sakit untuk menunjang kualitas layanan kesehatannya. Unit Rekam Medis merupakan salah satu gerbang terdepan dalam layanan dirumahsakit, sehingga dapat dijadikan pula sebagai salah satu ukuran kepuasan bagi konsumen kesehatan. Unit RekamMedis (URM) harus mampu menyediakan informasi yang cepat, tepat dan akurat, dimana tugas URM mulai dari penerimaan pasien, pengumpulan data dan penyajian informasi kesehatan. Untuk meningkatkan kualitas layanan, yaitu kepuasan konsuen maka dilakukan analisa dengan menggunakan metode Quality Function Deployment (QFD) diman ametode ini adalah metode yang berorientasi padase jauhmana tingkat kepuasan konsumen dengan spesifikasi keinginan konsumen tetapi juga mempertimbangkan kemampuan teknis perusahaan. Dengan metode ini pula pihak rumah sakit akan mengetahui variabel mana yang perlu dipertahankan atau ditingkatkan kualitas layanannya.

\section{TINJAUAN PUSTAKA}

\section{Rumah Sakit}

KeputusanMenteriRepublik Indonesia No 983/ MENKES/SK/1992 mengenai pedoman rumah sakit umum menyatakan bahwa:"Rumah Sakit Umum 
adalah rumah sakit yang memberikan pelayanan kesehatan yang bersifa tdasar, spealistik dan pendidikan tenagakesehatan dan pelatihan".

Rumah Sakit merupakan suatusistem/bagian dari sistem pelayanan kesehatan dan mempunyai tiga pilar otoritas yang masing-masing bekerja secara otonom namun harus terkoordinasi dalam system tersebut (Hatta, 2008).

RumahSakit adalah institusi pelayanan kesehatan yang menyelenggarakan pelayanan kesehatan perorangan secara paripurna yang menyediakan pelayanan rawatinap ,rawatjalan dan gawatdarurat (UU No.44Tahun, 2009).

\section{Kualitas dan Mutu Layanan}

Kualitas adalah suatu kondisi dinamis yang berhubungan dengan produk, manusia/tenagakerja, proses dantugas, serta lingkungan yang memenuhi atau melebihi harapan pelanggan atau konsumen (Nasution, 2011).

Mutu merupakan keseluruhan karekteristik barang atau jasa yang menunjukkan kemampuannya dalam memuaskan kebutuhan konsumen, baik berupa kebutuhan yang dinyatakan ataupun kebutuhan yang tersirat (Pohan, 2007)

Pada kualitas ada beberapad imensi pokok yang erat kaitannya dengan kualitas. Zeithaml, Berry, dan Parasuraman (dalam Tjiptono,2005) mengidentifikasikan lima dimensi pokok yang berkaitandengan jasa diantaranya :

1. Bukti langsung (tangibles)

2. Keandalan (reliability)

3. Daya tanggap (responsiveness)

4. Jaminan (assurance)

5. Empati

\section{Tahap-Tahap Implementasi QFD}

\section{Tahap pengumpulan Voice of Customer}

Pada tahapan ini dilakukan survey untuk mendapatkan suara dari responden. Prosedur umum dalam perolehan data suara pelanggan biasanya adalah menentukan data kualitatif dan data kuantitatif. Data kualitatif umumnya didapatkan dari pembicaraan dan obeservasi terhadap user. Sedangkan kuantitatif didapatkan dari survey dan penarikansuara ( Polls ).

\section{Tahapan penyusunan rumah kualitas (House of Quality)}

Tahap I Matrik Kebutuhan Pelanggan

Tahap ini meliputi :

1. Memutuskan siapa pelanggan

2. Mengumpulkan data kualitatif

3. Menyusun kebutuhan-kebutuhan tersebut

Tahap II Matrik Perencanaan

Tahap ini bertujuan untuk:

1. Mengukur kebutuhan pelanggan

2. Menetukan tujuan performasi kepuasan

Tahap III Respon Teknis

Tahap ini merupakan tranformasi dari kebutuhan yang bersifat non teknis data yang bersifat teknis guna memenuhi kebutuhan-kebutuhan tersebut

Tahap IV Menentukan Hubungan ResponTeknis dengan Kebutuhan Pelanggan

Tahap V KorelasiTeknis

Tahap VI Benchmarking dan Penetapan Target

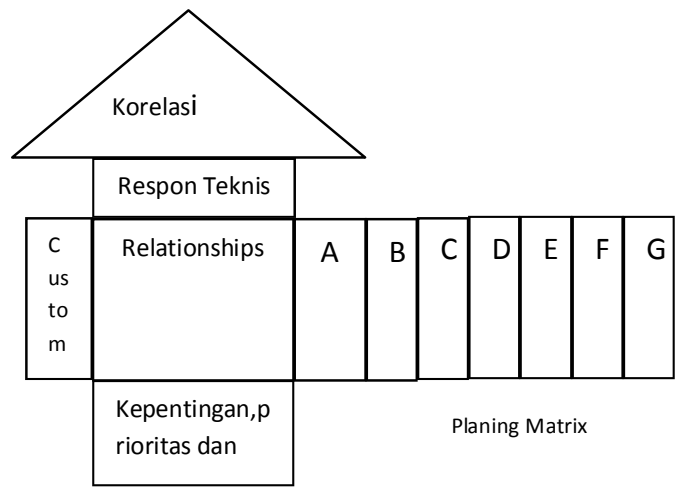

Gambar 1 Rumah Kualitas
A. Important to customer
B. Customer Statisfaction Performance
C. Goal
D. Improvement ratio
E. Sales point
F. Raw weight
G. Normalized Raw Weight

\section{Uji Validitas}

Uji validitas digunakan untuk mengukur apa yang seharusnya diukur. Perhitungan uji validitas ini menggunakan alat bantu komputer dengan program microsoft excel 2007. Suatu butir kuesioner dinyatakan valid apabila $r_{\text {hitung }}>r_{\text {tabel }}$ dan $r_{\text {hitung }}$ bernilai positif, rtabeluntuk $n=46$ adalah sebesar 0,291 . Hasil perhitungan uji validitas tiga kuesioner. 


\section{Uji Reliabilitas}

Uji reliabilitas digunakan untuk melihat tingkat konsistensi dari konsumen terhadap variabel yang ada. Uji reliabilitas dilakukan dengan menggunakan program SPSS 16.

\section{Penerapan Quality Function Deployment}

1. Customer needs

2. Matrik Perencanaan

a. Important to customer

Jumlah rata-rata : total responden

b. Customer Statisfaction Performance $\Sigma$ (Skala tk. kepuasan) $\times \Sigma$ responden

total responden

c. Goal

$\Sigma$ (skala tk. kepuasan harapa) $\times \Sigma$ responden total responden

d. Improvement Ratio

$\frac{\text { goal }}{\text { customer statisfaction performance }}$

e. Sales Point

f. Raw Weight

(important to costumer $) \times($ improvement ratio $) \times($ sales point $)$

g. Normalized Raw Weight $\frac{\text { raw weight }}{\text { total raw weight }}$

3. Matriks Relasi dan Prioritas

\begin{tabular}{|c|c|c|}
\hline Simbol & Nilai & Pengertian \\
\hline$<$ kosong $>$ & 0 & Tidakadahubungan \\
\hline$\triangle$ & 1 & Mungkinadahubungan \\
\hline$\bigcirc$ & 3 & Hubungannyasedang \\
\hline$\bigcirc$ & 9 & Sangatkuathubungannya \\
\hline
\end{tabular}

4. Korelasi Teknik (Technical Corellation)

\begin{tabular}{|c|l|}
\hline Simbol & \multicolumn{1}{|c|}{ Pengertian } \\
\hline$\bigcirc$ & Pengaruh positif sangat kuat \\
\hline$\bigcirc$ & Pengaruh positif cukup kuat \\
\hline$<$ kosong $>$ & Tidak ada pengaruh \\
\hline $\mathrm{X}$ & Pengaruh negatif cukup kuat \\
\hline $\mathrm{XX}$ & Pengaruh negatif sangat kuat \\
\hline
\end{tabular}

5. Penentuan Target

Target merupakan tujuan akhir yang ingin dicapai dengan menggambarkan bagaimana respon teknis yang telah disebutkan sebelumnya sesuai dengan kebutuhan pelanggan atau tidak, peneliti Untuk mengetahui target yang hendak dicapai, dilakukan penilaian dengan memberikan skala 1 sampai 5. Angka 1 menunjukkan level yang akan dicapai rendah dan angka 5 menunjukan level yang akan dicapai sangat tinggi.

\section{METODELOGI PENELITIAN}

\section{Populasi dan Sampel Penelitian}

Populasi dalam penelitian ini adalah pelanggan internal RSD Kalisat yaitu perawat yang berhubungan dengan unit rekam medis. Sample untuk penelitian ini adalah seluruh perawat RSD Kalisat Jember, untuk menentukan sample digunakan rumus :

$$
\mathrm{n}=\frac{\mathrm{N}}{1+\mathrm{N}\left(\mathrm{d}^{2}\right)}
$$

$$
\begin{aligned}
& \mathrm{n}=\frac{86}{1+86\left(0,1^{2}\right)} \\
& \mathrm{n}=46,2=46
\end{aligned}
$$

\section{HASIL DAN PEMBAHASAN}

\section{Uji Validitas}

Dalam penelitian ini uji validitas dilakukan terhadap 3 jenis kuesioner yaitu kuesioner tingkat kepentingan, kuesioner tingkat kepuasan dan kuesioner tingkat harapan dari perawat RSD Kalisat Jember

\section{Tabel 1 Uji Validitas Kuesioner Tingkat Kepentingan}

\begin{tabular}{|c|l|c|c|c|}
\hline No & \multicolumn{1}{|c|}{ Atribut } & $\mathbf{r}_{\text {hitung }}$ & $\mathbf{r}_{\text {tabel }}$ & Status \\
\hline 1 & $\begin{array}{l}\text { Letak gedung (URM) } \\
\text { yang strategis dari } \\
\text { rawat jalan }\end{array}$ & 0.576 & 0,291 & Valid \\
\hline 2 & $\begin{array}{l}\text { Letak gedung URM) } \\
\text { yang strategis dari } \\
\text { rawat inap }\end{array}$ & 0.515 & 0,291 & Valid \\
\hline 3 & $\begin{array}{l}\text { Ruang penyimpanan } \\
\text { yang luas }\end{array}$ & 0.462 & 0,291 & Valid \\
\hline 4 & $\begin{array}{l}\text { Perlengkapan Rekam } \\
\text { medis }\end{array}$ & 0.592 & 0,291 & Valid \\
\hline 5 & Jumlah pegawai & 0.609 & 0,291 & Valid \\
\hline 6 & Sarana komunikasi & 0.465 & 0,291 & Valid \\
\hline 7 & $\begin{array}{l}\text { Kecepatan penyediaan } \\
\text { berkas RM }\end{array}$ & 0.677 & 0,291 & Valid \\
\hline
\end{tabular}




\begin{tabular}{|c|l|c|c|c|}
\hline No & \multicolumn{1}{|c|}{ Atribut } & $\mathbf{r}_{\text {hitung }}$ & $\mathbf{r}_{\text {tabel }}$ & Status \\
\hline 8 & $\begin{array}{l}\text { Ketelitian dalam } \\
\text { pengambilan berkas } \\
\text { RM }\end{array}$ & 0.603 & 0,291 & Valid \\
\hline 9 & Kesesuaian informasi & 0.607 & 0,291 & Valid \\
\hline 10 & $\begin{array}{l}\text { Kesiapan petugas } \\
\text { rekam medis }\end{array}$ & 0.588 & 0,291 & Valid \\
\hline 11 & $\begin{array}{l}\text { Ketepatan dalam } \\
\text { pengambilan berkas } \\
\text { RM }\end{array}$ & 0.510 & 0,291 & Valid \\
\hline 12 & Keramahan petugas & 0.542 & 0,291 & Valid \\
\hline 13 & $\begin{array}{l}\text { Keamanan } \\
\text { penyimpanan berkas } \\
\text { RM }\end{array}$ & 0.723 & 0,291 & Valid \\
\hline 14 & $\begin{array}{l}\text { Sikap petugas dalam } \\
\text { menghadapi perawat }\end{array}$ & 0.509 & 0,291 & Valid \\
\hline 15 & $\begin{array}{l}\text { Kecepatan dalam } \\
\text { pemberian informasi } \\
\text { dan penyediaan berkas }\end{array}$ & 0.720 & 0,291 & Valid \\
\hline 16 & $\begin{array}{l}\text { Kemudahan dalam } \\
\text { melakukan hubungan }\end{array}$ & 0.602 & 0,291 & Valid \\
\hline 17 & Komunikasi & 0.540 & 0,291 & Valid \\
\hline
\end{tabular}

Tabel 2. Uji Validitas Kuesioner Tingkat Kepuasan yang Dirasakan (Perceived Performance)

\begin{tabular}{|c|l|c|c|c|}
\hline No & \multicolumn{1}{|c|}{ Atribut } & $\mathbf{r}_{\text {hitung }}$ & $\mathbf{r}_{\text {tabel }}$ & Status \\
\hline 1 & $\begin{array}{l}\text { Letak gedung (URM) } \\
\text { yang strategis dari } \\
\text { rawat jalan }\end{array}$ & 0.506 & 0,291 & Valid \\
\hline 2 & $\begin{array}{l}\text { Letak gedung (URM) } \\
\text { yang strategis dari } \\
\text { rawat inap }\end{array}$ & 0.512 & 0,291 & Valid \\
\hline 3 & $\begin{array}{l}\text { Ruang penyimpanan } \\
\text { yang luas }\end{array}$ & 0.540 & 0,291 & Valid \\
\hline 4 & $\begin{array}{l}\text { Perlengkapan Rekam } \\
\text { medis }\end{array}$ & 0.538 & 0,291 & Valid \\
\hline 5 & Jumlah pegawai & 0.480 & 0,291 & Valid \\
\hline 6 & Sarana komunikasi & 0.479 & 0,291 & Valid \\
\hline 7 & $\begin{array}{l}\text { Kecepatan penyediaan } \\
\text { berkas RM }\end{array}$ & 0.508 & 0,291 & Valid \\
\hline 8 & $\begin{array}{l}\text { Ketelitian dalam } \\
\text { pengambilan berkas } \\
\text { RM }\end{array}$ & 0.552 & 0,291 & Valid \\
\hline 9 & Kesesuaian informasi & 0.540 & 0,291 & Valid \\
\hline 10 & $\begin{array}{l}\text { Kesiapan petugas } \\
\text { rekam medis }\end{array}$ & 0.589 & 0,291 & Valid \\
\hline
\end{tabular}

\begin{tabular}{|c|l|c|c|c|}
\hline No & \multicolumn{1}{|c|}{ Atribut } & $\mathbf{r}_{\text {hitung }}$ & $\mathbf{r}_{\text {tabel }}$ & Status \\
\hline 11 & $\begin{array}{l}\text { Ketepatan dalam } \\
\text { pengambilan berkas } \\
\text { RM }\end{array}$ & 0.566 & 0,291 & Valid \\
\hline 12 & Keramahan petugas & 0.570 & 0,291 & Valid \\
\hline 13 & $\begin{array}{l}\text { Keamanan } \\
\text { penyimpanan berkas } \\
\text { RM }\end{array}$ & 0.568 & 0,291 & Valid \\
\hline 14 & $\begin{array}{l}\text { Sikap petugas dalam } \\
\text { menghadapi perawat }\end{array}$ & 0.597 & 0,291 & Valid \\
\hline 15 & $\begin{array}{l}\text { Kecepatan dalam } \\
\text { pemberian informasi } \\
\text { dan penyediaan berkas }\end{array}$ & 0.570 & 0,291 & Valid \\
\hline 16 & $\begin{array}{l}\text { Kemudahan dalam } \\
\text { melkukan hubungan }\end{array}$ & 0.552 & 0,291 & Valid \\
\hline 17 & Komunikasi & 0.540 & 0,291 & Valid \\
\hline
\end{tabular}

Tabel 3. Uji Validitas Kuesioner Tingkat Kepuasan yang Diharapkan (Expected Performance)

\begin{tabular}{|c|l|c|c|c|}
\hline No & \multicolumn{1}{|c|}{ Atribut } & $\mathbf{r}_{\text {hitung }}$ & $\mathbf{r}_{\text {tabel }}$ & Status \\
\hline 1 & $\begin{array}{l}\text { Letak gedung (URM) } \\
\text { yang strategis dari } \\
\text { rawat jalan }\end{array}$ & 0.422 & 0,291 & Valid \\
\hline 2 & $\begin{array}{l}\text { Letak gedung (URM) } \\
\text { yang strategis dari } \\
\text { rawat inap }\end{array}$ & 0.482 & 0,291 & Valid \\
\hline 3 & $\begin{array}{l}\text { Ruang penyimpanan } \\
\text { yang luas }\end{array}$ & 0.466 & 0,291 & Valid \\
\hline 4 & $\begin{array}{l}\text { Perlengkapan Rekam } \\
\text { medis }\end{array}$ & 0.505 & 0,291 & Valid \\
\hline 5 & Jumlah pegawai & 0.463 & 0,291 & Valid \\
\hline 6 & Sarana komunikasi & 0.468 & 0,291 & Valid \\
\hline 7 & $\begin{array}{l}\text { Kecepatan penyediaan } \\
\text { berkas RM }\end{array}$ & 0.478 & 0,291 & Valid \\
\hline 8 & $\begin{array}{l}\text { Ketelitian dalam } \\
\text { pengambilan berkas } \\
\text { RM }\end{array}$ & 0.440 & 0,291 & Valid \\
\hline 9 & Kesesuaian informasi & 0.432 & 0,291 & Valid \\
\hline 10 & $\begin{array}{l}\text { Kesiapan petugas } \\
\text { rekam medis }\end{array}$ & 0.535 & 0,291 & Valid \\
\hline 11 & $\begin{array}{l}\text { Ketepatan dalam } \\
\text { Rengambilan berkas }\end{array}$ & 0.505 & 0,291 & Valid \\
\hline 12 & Keramahan petugas & 0.463 & 0,291 & Valid \\
\hline 13 & $\begin{array}{l}\text { Keamanan } \\
\text { Renyimpanan berkas }\end{array}$ & 0.519 & 0,291 & Valid \\
\hline
\end{tabular}




\begin{tabular}{|c|l|c|c|c|}
\hline No & \multicolumn{1}{|c|}{ Atribut } & $\mathbf{r}_{\text {hitung }}$ & $\mathbf{r}_{\text {tabel }}$ & Status \\
\hline 14 & $\begin{array}{l}\text { Sikap petugas dalam } \\
\text { menghadapi perawat }\end{array}$ & 0.478 & 0,291 & Valid \\
\hline 15 & $\begin{array}{l}\text { Kecepatan dalam } \\
\text { pemberian informasi } \\
\text { dan penyediaan berkas }\end{array}$ & 0.464 & 0,291 & Valid \\
\hline 16 & $\begin{array}{l}\text { Kemudahan dalam } \\
\text { melkukan hubungan }\end{array}$ & 0.441 & 0,291 & Valid \\
\hline 17 & Komunikasi & 0.468 & 0,291 & Valid \\
\hline
\end{tabular}

\section{PenerapanQuality Function Deployment}

\section{Customer needs}

Customer needsmerupakan data yang berisikan kebutuhan dan keinginan pelanggan yang didapatkan setelah pembuatan diagram afinitas. Data tersebut dapat dilihat pada berikut ini :

\section{Tabel 4. Customer needs}

\begin{tabular}{|c|c|}
\hline \multicolumn{2}{|c|}{ Customer Requirments (What's) } \\
\hline \multirow{6}{*}{$\begin{array}{l}\text { Bukti langsung } \\
\text { (tangibles) }\end{array}$} & $\begin{array}{l}\text { 1. Letak gedung (URM) } \\
\text { yang strategis dari rawat } \\
\text { jalan }\end{array}$ \\
\hline & $\begin{array}{l}\text { 2. Letak gedung Medis } \\
\text { (URM) yang strategis } \\
\text { dari rawat inap }\end{array}$ \\
\hline & $\begin{array}{l}\text { 3. Ruang penyimpanan yang } \\
\text { luas }\end{array}$ \\
\hline & $\begin{array}{l}\text { 4. Perlengkapan Rekam } \\
\text { medis }\end{array}$ \\
\hline & 5. Jumlah pegawai \\
\hline & 6. Sarana komunikasi \\
\hline \multirow{2}{*}{$\begin{array}{l}\text { Kehandalan } \\
\text { (reliability) }\end{array}$} & $\begin{array}{l}\text { 7. Kecepatan penyediaan } \\
\text { berkas RM }\end{array}$ \\
\hline & $\begin{array}{ll}\text { 8. } & \text { Ketelitian dalam } \\
\text { pengambilan berkas RM }\end{array}$ \\
\hline \multirow{4}{*}{$\begin{array}{l}\text { Daya tanggap } \\
\text { (responsiveness) }\end{array}$} & 9. Kesesuaian informasi \\
\hline & $\begin{array}{l}\text { 10. Kesiapan petugas rekam } \\
\text { medis }\end{array}$ \\
\hline & $\begin{array}{l}\text { 11. Ketepatan dalam } \\
\text { pengambilan berkas RM }\end{array}$ \\
\hline & 12. Keramahan petugas \\
\hline \multirow{3}{*}{$\begin{array}{l}\text { Jaminan } \\
\text { (assurance) }\end{array}$} & $\begin{array}{l}\text { 13. Keamanan penyimpanan } \\
\text { berkas RM }\end{array}$ \\
\hline & $\begin{array}{l}\text { 14. Sikap petugas dalam } \\
\text { menghadapi perawat }\end{array}$ \\
\hline & $\begin{array}{l}\text { 15. Kecepatan dalam } \\
\text { pemberian informasi dan } \\
\text { penyediaan berkas }\end{array}$ \\
\hline \multirow[t]{2}{*}{ Emphati } & $\begin{array}{l}\text { 16. Kemudahan dalam } \\
\text { melakukan hubungan }\end{array}$ \\
\hline & 17. Komunikasi \\
\hline
\end{tabular}

2. Matrik Perencanaan

Tabel 5. Important to Customer (Nilai Tingkat Kepentingan)

\begin{tabular}{|c|c|c|c|}
\hline No & Atribut & $\begin{array}{l}\text { Rata- } \\
\text { rata }\end{array}$ & Peringkat \\
\hline 1 & $\begin{array}{l}\text { Letak gedung (URM) } \\
\text { yang strategis dari } \\
\text { rawat jalan }\end{array}$ & 4.21 & 10 \\
\hline 2 & $\begin{array}{l}\text { Letak gedung (URM) } \\
\text { yang strategis dari } \\
\text { rawat inap }\end{array}$ & 4.06 & 13 \\
\hline 3 & $\begin{array}{l}\text { Ruang penyimpanan } \\
\text { yang luas }\end{array}$ & 3.97 & 14 \\
\hline 4 & $\begin{array}{l}\text { Perlengkapan Rekam } \\
\text { medis }\end{array}$ & 4.17 & 12 \\
\hline 5 & Jumlah pegawai & 3.82 & 15 \\
\hline 6 & Sarana komunikasi & 4.32 & 6 \\
\hline 7 & $\begin{array}{l}\text { Kecepatan penyediaan } \\
\text { berkas RM }\end{array}$ & 4.30 & 8 \\
\hline 8 & $\begin{array}{l}\text { Ketelitian dalam } \\
\text { pengambilan berkas } \\
\text { RM }\end{array}$ & 4.36 & 5 \\
\hline 9 & Kesesuaian informasi & 4.19 & 11 \\
\hline 10 & $\begin{array}{l}\text { Kesiapan petugas } \\
\text { rekam medis }\end{array}$ & 4.36 & 5 \\
\hline 11 & $\begin{array}{l}\text { Ketepatan dalam } \\
\text { pengambilan berkas } \\
\text { RM }\end{array}$ & 4.39 & 4 \\
\hline 12 & Keramahan petugas & 4.30 & 8 \\
\hline 13 & $\begin{array}{l}\text { Keamanan } \\
\text { penyimpanan berkas } \\
\text { RM }\end{array}$ & 4.47 & 2 \\
\hline 14 & $\begin{array}{l}\text { Sikap petugas dalam } \\
\text { menghadapi perawat }\end{array}$ & 4.58 & 1 \\
\hline 15 & $\begin{array}{l}\text { Kecepatan dalam } \\
\text { pemberian informasi } \\
\text { dan penyediaan berkas }\end{array}$ & 4.32 & 7 \\
\hline 16 & $\begin{array}{l}\text { Kemudahan dalam } \\
\text { melkukan hubungan }\end{array}$ & 4.23 & 9 \\
\hline 17 & Komunikasi & 4.43 & 3 \\
\hline
\end{tabular}


Tabel 6. Customer SatisfactionPerformma nce(Penentuan Tingkat Kepuasan)

\begin{tabular}{|c|c|c|c|c|}
\hline No & Atribut & $\begin{array}{c}\text { Number } \\
\text { of Res- } \\
\text { pondent }\end{array}$ & $\begin{array}{c}\text { Perfor- } \\
\text { mance } \\
\text { Weight }\end{array}$ & $\begin{array}{c}\text { Weighted } \\
\text { Average } \\
\text { Perfor- } \\
\text { mance } \\
\text { (Perceived } \\
\text { scale) }\end{array}$ \\
\hline 1 & $\begin{array}{l}\text { Letak gedung } \\
\text { (URM) yang } \\
\text { strategis dari } \\
\text { rawat jalan }\end{array}$ & 46 & 167 & 3.63 \\
\hline 2 & $\begin{array}{l}\text { Letak gedung } \\
\text { (URM) yang } \\
\text { strategis dari } \\
\text { rawat inap }\end{array}$ & 46 & 172 & 3.73 \\
\hline 3 & $\begin{array}{l}\text { Ruang } \\
\text { penyimpanan } \\
\text { yang luas }\end{array}$ & 46 & 165 & 3.58 \\
\hline 4 & $\begin{array}{l}\text { Perlengkapan } \\
\text { Rekam medis }\end{array}$ & 46 & 167 & 3.63 \\
\hline 5 & Jumlah pegawai & 46 & 172 & 3.73 \\
\hline 6 & $\begin{array}{l}\text { Sarana } \\
\text { komunikasi }\end{array}$ & 46 & 164 & 3.56 \\
\hline 7 & $\begin{array}{l}\text { Kecepatan } \\
\text { penyediaan } \\
\text { berkas RM }\end{array}$ & 46 & 167 & 3.63 \\
\hline 8 & $\begin{array}{l}\text { Ketelitian } \\
\text { dalam } \\
\text { pengambilan } \\
\text { berkas RM }\end{array}$ & 46 & 172 & 3.73 \\
\hline 9 & $\begin{array}{l}\text { Kesesuaian } \\
\text { informasi }\end{array}$ & 46 & 165 & 3.58 \\
\hline 10 & $\begin{array}{l}\text { Kesiapan } \\
\text { petugas rekam } \\
\text { medis }\end{array}$ & 46 & 169 & 3.67 \\
\hline 11 & $\begin{array}{l}\text { Ketepatan } \\
\text { dalam } \\
\text { pengambilan } \\
\text { berkas RM }\end{array}$ & 46 & 173 & 3.76 \\
\hline 12 & $\begin{array}{l}\text { Keramahan } \\
\text { petugas }\end{array}$ & 46 & 166 & 3.60 \\
\hline 13 & $\begin{array}{l}\text { Keamanan } \\
\text { penyimpanan } \\
\text { berkas RM }\end{array}$ & 46 & 168 & 3.65 \\
\hline 14 & $\begin{array}{l}\text { Sikap petugas } \\
\text { dalam } \\
\text { menghadapi } \\
\text { perawat }\end{array}$ & 46 & 174 & 3.78 \\
\hline
\end{tabular}

\begin{tabular}{|c|l|c|c|c|}
\hline No & \multicolumn{1}{|c|}{ Atribut } & $\begin{array}{c}\text { Number } \\
\text { of Res- } \\
\text { pondent }\end{array}$ & $\begin{array}{c}\text { Weighted } \\
\text { mance } \\
\text { Weight } \\
\text { Average } \\
\text { Perfor- } \\
\text { mance } \\
\text { (Perceived } \\
\text { scale) }\end{array}$ \\
\hline 15 & $\begin{array}{l}\text { Kecepatan } \\
\text { dalam } \\
\text { pemberian } \\
\text { informasi dan } \\
\text { penyediaan } \\
\text { berkas }\end{array}$ & 46 & 166 & 3.60 \\
\hline 16 & $\begin{array}{l}\text { Kemudahan } \\
\text { dalam } \\
\text { melkukan } \\
\text { hubungan }\end{array}$ & 46 & 172 & 3.73 \\
\hline 17 & Komunikasi & 46 & 165 & 3.58 \\
\hline
\end{tabular}

Tabel 7. Goal

\begin{tabular}{|c|c|c|c|c|}
\hline No & Atribut & $\begin{array}{l}\text { Number } \\
\text { of Res- } \\
\text { pondent }\end{array}$ & $\begin{array}{l}\text { Perfor- } \\
\text { mance } \\
\text { Weight }\end{array}$ & Goal \\
\hline 1 & $\begin{array}{l}\text { Letak gedung } \\
\text { (URM) yang } \\
\text { strategis dari rawat } \\
\text { jalan }\end{array}$ & 46 & 198 & 4.30 \\
\hline 2 & $\begin{array}{l}\text { Letak gedung } \\
\text { (URM) yang } \\
\text { strategis dari rawat } \\
\text { inap }\end{array}$ & 46 & 201 & 4.36 \\
\hline 3 & $\begin{array}{l}\text { Ruang penyimpanan } \\
\text { yang luas }\end{array}$ & 46 & 203 & 4.41 \\
\hline 4 & $\begin{array}{l}\text { Perlengkapan } \\
\text { Rekam medis }\end{array}$ & 46 & 202 & 4.39 \\
\hline 5 & Jumlah pegawai & 46 & 202 & 4.39 \\
\hline 6 & Sarana komunikasi & 46 & 208 & 4.52 \\
\hline 7 & $\begin{array}{l}\text { Kecepatan } \\
\text { penyediaan berkas } \\
\text { RM }\end{array}$ & 46 & 203 & 4.41 \\
\hline 8 & $\begin{array}{l}\text { Ketelitian dalam } \\
\text { pengambilan berkas } \\
\text { RM }\end{array}$ & 46 & 201 & 4.36 \\
\hline 9 & $\begin{array}{l}\text { Kesesuaian } \\
\text { informasi }\end{array}$ & 46 & 208 & 4.52 \\
\hline 10 & $\begin{array}{l}\text { Kesiapan petugas } \\
\text { rekam medis }\end{array}$ & 46 & 216 & 4.69 \\
\hline 11 & $\begin{array}{l}\text { Ketepatan dalam } \\
\text { pengambilan berkas } \\
\text { RM }\end{array}$ & 46 & 202 & 4.39 \\
\hline 12 & Keramahan petugas & 46 & 202 & 4.39 \\
\hline
\end{tabular}




\begin{tabular}{|c|l|c|c|c|}
\hline No & \multicolumn{1}{|c|}{ Atribut } & $\begin{array}{c}\text { Number } \\
\text { of Res- } \\
\text { pondent }\end{array}$ & $\begin{array}{c}\text { Perfor- } \\
\text { mance } \\
\text { Weight }\end{array}$ & Goal \\
\hline 13 & $\begin{array}{l}\text { Keamanan } \\
\text { penyimpanan } \\
\text { berkas RM }\end{array}$ & 46 & 208 & 4.52 \\
\hline 14 & $\begin{array}{l}\text { Sikap petugas } \\
\text { dalam menghadapi } \\
\text { perawat }\end{array}$ & 46 & 203 & 4.41 \\
\hline 15 & $\begin{array}{l}\text { Kecepatan } \\
\text { dalam pemberian } \\
\text { informasi dan } \\
\text { penyediaan berkas }\end{array}$ & 46 & 202 & 4.39 \\
\hline 16 & $\begin{array}{l}\text { Kemudahan dalam } \\
\text { melkukan hubungan }\end{array}$ & 46 & 208 & 4.52 \\
\hline 17 & Komunikasi & 46 & 212 & 4.60 \\
\hline
\end{tabular}

Tabel 8. Improvement Ratio

\begin{tabular}{|c|c|c|}
\hline No & Atribut & $\begin{array}{c}\text { Improvement } \\
\text { Ratio }\end{array}$ \\
\hline 1 & $\begin{array}{l}\text { Letak gedung (URM) yang } \\
\text { strategis dari rawat jalan }\end{array}$ & 1,184 \\
\hline 2 & $\begin{array}{l}\text { Letak gedung (URM) yang } \\
\text { strategis dari rawat inap }\end{array}$ & 1,168 \\
\hline 3 & $\begin{array}{l}\text { Ruang penyimpanan yang } \\
\text { luas }\end{array}$ & 1,231 \\
\hline 4 & $\begin{array}{l}\text { Perlengkapan Rekam } \\
\text { medis }\end{array}$ & 1,209 \\
\hline 5 & Jumlah pegawai & 1,176 \\
\hline 6 & Sarana komunikasi & 1,269 \\
\hline 7 & $\begin{array}{l}\text { Kecepatan penyediaan } \\
\text { berkas RM }\end{array}$ & 1,214 \\
\hline 8 & $\begin{array}{l}\text { Ketelitian dalam } \\
\text { pengambilan berkas RM }\end{array}$ & 1,168 \\
\hline 9 & Kesesuaian informasi & 1,262 \\
\hline 10 & $\begin{array}{l}\text { Kesiapan petugas rekam } \\
\text { medis }\end{array}$ & 1,277 \\
\hline 11 & $\begin{array}{l}\text { Ketepatan dalam } \\
\text { pengambilan berkas RM }\end{array}$ & 1,167 \\
\hline 12 & Keramahan petugas & 1,219 \\
\hline 13 & $\begin{array}{l}\text { Keamanan penyimpanan } \\
\text { berkas RM }\end{array}$ & 1,238 \\
\hline 14 & $\begin{array}{l}\text { Sikap petugas dalam } \\
\text { menghadapi perawat }\end{array}$ & 1,166 \\
\hline 15 & $\begin{array}{l}\text { Kecepatan dalam } \\
\text { pemberian informasi dan } \\
\text { penyediaan berkas }\end{array}$ & 1,219 \\
\hline 16 & $\begin{array}{l}\text { Kemudahan dalam } \\
\text { melkukan hubungan }\end{array}$ & 1,211 \\
\hline 17 & Komunikasi & 1,284 \\
\hline
\end{tabular}

Sales Point berisi informasi tentang kemampuan dalam menjual produk atau jasa, didasarkan pada seberapa baik tiap kebutuhan pelanggan dapat terpenuhi, berikut adalah nilai dari sales point :

Tabel 9. Sales Point

\begin{tabular}{|c|l|c|}
\hline No & \multicolumn{1}{|c|}{ Atribut } & $\begin{array}{c}\text { Sales } \\
\text { point }\end{array}$ \\
\hline 1 & $\begin{array}{l}\text { Letak gedung (URM) yang } \\
\text { strategis dari rawat jalan }\end{array}$ & 1,5 \\
\hline 2 & $\begin{array}{l}\text { Letak gedung (URM) yang } \\
\text { strategis dari rawat inap }\end{array}$ & 1,5 \\
\hline 3 & Ruang penyimpanan yang luas & 1,5 \\
\hline 4 & Perlengkapan Rekam medis & 1,5 \\
\hline 5 & Jumlah pegawai & 1,5 \\
\hline 6 & Sarana komunikasi & 1,2 \\
\hline 7 & Kecepatan penyediaan berkas RM & 1,5 \\
\hline 8 & $\begin{array}{l}\text { Ketelitian dalam pengambilan } \\
\text { berkas RM }\end{array}$ & 1,5 \\
\hline 9 & Kesesuaian informasi & 1,5 \\
\hline 10 & Kesiapan petugas rekam medis & 1,5 \\
\hline 11 & $\begin{array}{l}\text { Ketepatan dalam pengambilan } \\
\text { berkas RM }\end{array}$ & 1,5 \\
\hline 12 & Keramahan petugas & 1,5 \\
\hline 13 & $\begin{array}{l}\text { Keamanan penyimpanan berkas } \\
\text { RM }\end{array}$ & 1,5 \\
\hline 14 & $\begin{array}{l}\text { Sikap petugas dalam menghadapi } \\
\text { perawat }\end{array}$ & 1,5 \\
\hline 15 & $\begin{array}{l}\text { Kecepatan dalam pemberian } \\
\text { informasi dan penyediaan berkas }\end{array}$ \\
\hline 16 & $\begin{array}{l}\text { Kemudahan dalam melkukan } \\
\text { hubungan }\end{array}$ & 1,2 \\
\hline 17 & Komunikasi & 1,2 \\
\hline & & \\
\hline
\end{tabular}

Tabel 10. Raw Weight

\begin{tabular}{|c|l|c|}
\hline No & \multicolumn{1}{|c|}{ Atribut } & $\begin{array}{c}\text { Raw } \\
\text { Weight }\end{array}$ \\
\hline 1 & $\begin{array}{l}\text { Letak gedung (URM) yang } \\
\text { strategis dari rawat jalan }\end{array}$ & 7,477 \\
\hline 2 & $\begin{array}{l}\text { Letak gedung (URM) yang } \\
\text { strategis dari rawat inap }\end{array}$ & 7,113 \\
\hline 3 & Ruang penyimpanan yang luas & 7,330 \\
\hline 4 & Perlengkapan Rekam medis & 7,562 \\
\hline 5 & Jumlah pegawai & 6,738 \\
\hline 6 & Sarana komunikasi & 6,578 \\
\hline 7 & $\begin{array}{l}\text { Kecepatan penyediaan berkas } \\
\text { RM }\end{array}$ & 7,830 \\
\hline 8 & $\begin{array}{l}\text { Ketelitian dalam pengambilan } \\
\text { berkas RM }\end{array}$ & 7,638 \\
\hline
\end{tabular}




\begin{tabular}{|c|l|c|}
\hline No & \multicolumn{1}{|c|}{ Atribut } & $\begin{array}{c}\text { Raw } \\
\text { Weight }\end{array}$ \\
\hline 9 & Kesesuaian informasi & 7,932 \\
\hline 10 & Kesiapan petugas rekam medis & 8,351 \\
\hline 11 & $\begin{array}{l}\text { Ketepatan dalam pengambilan } \\
\text { berkas RM }\end{array}$ & 7,685 \\
\hline 12 & Keramahan petugas & 7,862 \\
\hline 13 & $\begin{array}{l}\text { Keamanan penyimpanan berkas } \\
\text { RM }\end{array}$ & 8,300 \\
\hline 14 & $\begin{array}{l}\text { Sikap petugas dalam } \\
\text { menghadapi perawat }\end{array}$ & $\begin{array}{l}8,010 \\
\text { informasi dan penyediaan berkas }\end{array}$ \\
\hline 15 & $\begin{array}{l}\text { Kecepatan dalam pemberian } \\
\text { hubungan }\end{array}$ & 6,147 \\
\hline 17 & Komunikasi & 6,826 \\
\hline
\end{tabular}

Tabel 11. Normalized Raw Weight

\begin{tabular}{|c|l|c|}
\hline No & \multicolumn{1}{|c|}{ Atribut } & $\begin{array}{c}\text { Normalized } \\
\text { Raw Weight }\end{array}$ \\
\hline 1 & $\begin{array}{l}\text { Letak gedung (URM) yang } \\
\text { strategis dari rawat jalan }\end{array}$ & 0,0527 \\
\hline 2 & $\begin{array}{l}\text { Letak gedung (URM) yang } \\
\text { strategis dari rawat inap }\end{array}$ & 0,0501 \\
\hline 3 & $\begin{array}{l}\text { Ruang penyimpanan yang } \\
\text { luas }\end{array}$ & 0,0516 \\
\hline 4 & Perlengkapan Rekam medis & 0,0533 \\
\hline 5 & Jumlah pegawai & 0,0475 \\
\hline 6 & Sarana komunikasi & 0,0464 \\
\hline 7 & $\begin{array}{l}\text { Kecepatan penyediaan } \\
\text { berkas RM }\end{array}$ & 0,0552 \\
\hline 8 & $\begin{array}{l}\text { Ketelitian dalam } \\
\text { pengambilan berkas RM }\end{array}$ & 0,0538 \\
\hline 9 & Kesesuaian informasi & 0,0559 \\
\hline 10 & $\begin{array}{l}\text { Kesiapan petugas rekam } \\
\text { medis }\end{array}$ & 0,0588 \\
\hline 11 & $\begin{array}{l}\text { Ketepatan dalam } \\
\text { pengambilan berkas RM }\end{array}$ & 0,0542 \\
\hline 12 & Keramahan petugas & 0,0554 \\
\hline 13 & $\begin{array}{l}\text { Keamanan penyimpanan } \\
\text { berkas RM }\end{array}$ & $\begin{array}{l}\text { Sikap petugas dalam } \\
\text { menghadapi perawat }\end{array}$ \\
\hline 15 & $\begin{array}{l}\text { Kecepatan dalam pemberian } \\
\text { informasi dan penyediaan } \\
\text { berkas }\end{array}$ & 0,0556 \\
\hline 16 & $\begin{array}{l}\text { Kemudahan dalam } \\
\text { melkukan hubungan }\end{array}$ \\
\hline 17 & Komunikasi & 0,0433 \\
\hline
\end{tabular}

\section{Respon Teknis}

Respon teknis merupakan keinginan pelanggan yang diterjemahkan kedalam persyaratan teknis sehingga dapat diukur untuk menentukan target yang akan dicapai dan untuk menentukan atribut mana yang nantinya akan dikembangkan. Penentuan karakteristik teknis dilakukan oleh kepala rekam medis dan peneliti. Hasil selengkapnya dapat dilihat pada tabel berikut ini :

\section{Tabel 12. Respon Teknis}

\begin{tabular}{|c|l|}
\hline No & \multicolumn{1}{|c|}{ Technical Response (How's) } \\
\hline 1 & $\begin{array}{l}\text { Pengadaan URM ditempat yang strategis } \\
\text { (tengah) }\end{array}$ \\
\hline 2 & Penambahan Perlengkapan RM \\
\hline 3 & Pelatihan Internal dan eksternal \\
\hline 4 & $\begin{array}{l}\text { Ketaatan dalam menjalankan TDF ( Terminal } \\
\text { Digit Filling ) }\end{array}$ \\
\hline 5 & Penerapan Etika Profesi \\
\hline 6 & Kemampuan berkomunikasi dengan baik \\
\hline 7 & Letak tata ruang filling \\
\hline 8 & $\begin{array}{l}\text { Memperluas ruang, cahaya dan kualitas udara } \\
\text { yang baik }\end{array}$ \\
\hline 9 & Merevisi Protap yang ada \\
\hline
\end{tabular}

Setelah data-data tersebut diketahui selanjutnya akan dianalisis menggunakan House Of Qualitydan disajikan dalam bentuk rumah kualitas (house of quality).

\section{Matriks Relasi dan Prioritas}

Matriks relasi merupakan tahapan untuk menentukan ada tidaknya hubungan dengan tingkat performasi kepuasan pelanggan atau menentukan seberapa kuat hubungan antara respon teknis (technical respon) dalam memenuhi kebutuhan pelanggan ( customer needs). Penentuan karakteristik teknis dilakukan oleh kepala rekam medis dan peneliti Relasi kekuatan ini berupa simbol numerik

Hasil relasi antara respon teknis dan kebutuhan pelanggan, dapat dilihat pada gambar berikut:

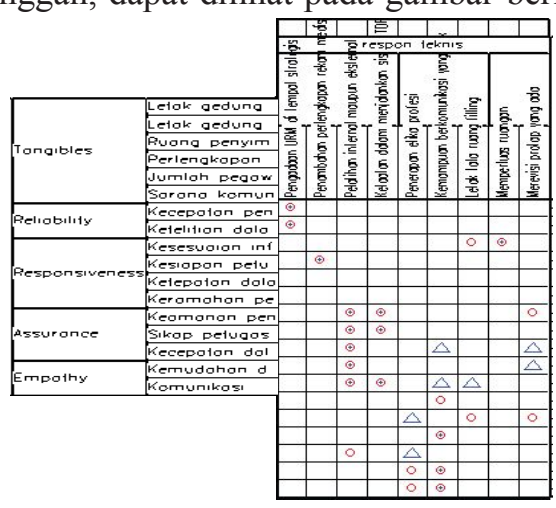

Gambar 1. Matrik Relasi 
Nilai kepentingan teknik (bobot) digunakan untuk mempresentasikan kontribusi relatif dari respon teknis terhadap kepuasan pelanggan, sehingga dapat diketahui respon teknis mana yang diprioritaskan untuk memperbaiki kebutuhan pelanggan.

\section{Korelasi Teknik}

Korelasi teknis (Technical Corellation) digunakan untuk mengidentifikasi hubungan antara masing - masing respon teknis

Tujuan penentuan korelasi ini digunakan untuk mempermudah dalam menentukan kebijakan yang akan diambil mengenai penentuan respon teknis mana yang akan dilaksanakan, berikut adalah hasil identifikasi hubungan antara masing - masing respon teknis :

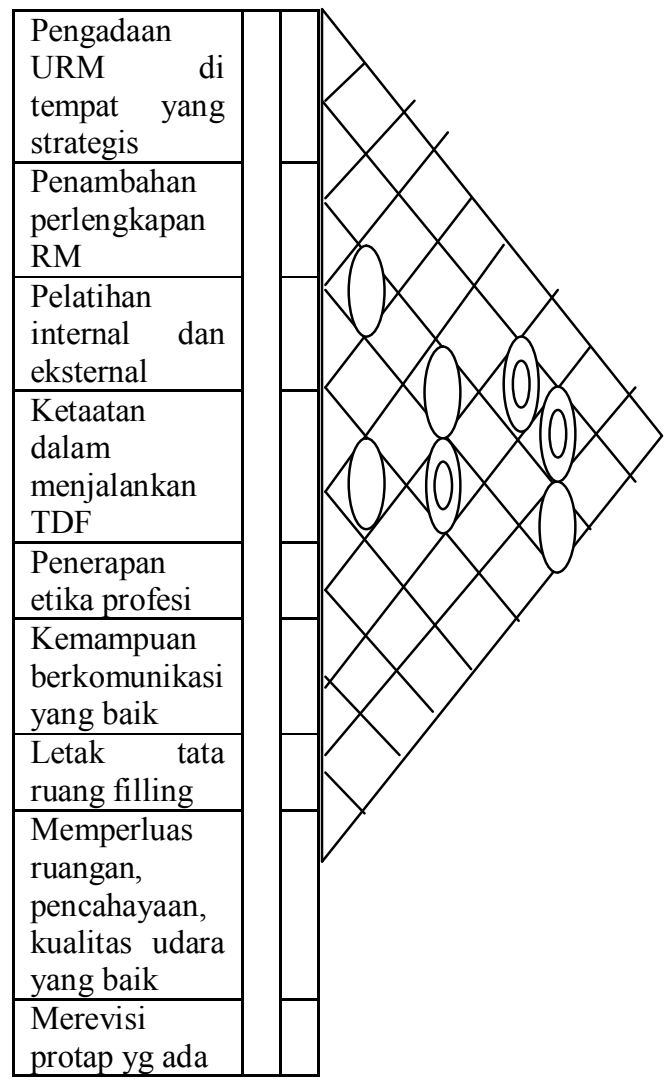

Gambar 2. Korelasi Teknik

\section{Penentuan target}

Target merupakan tujuan akhir yang ingin dicapai dengan menggambarkan bagaimana respon teknis yang telah disebutkan sebelumnya sesuai dengan kebutuhan pelanggan atau tidak. Apakah respon teknis tersebut akan ditingkatkan, diturunkan atau bahkan merupakan target yang diinginkan. Penentuan target dilakukan oleh kepala rekam medis dan peneliti Untuk mengetahui target yang hendak dicapai, dilakukan penilaian dengan memberikan skala 1 sampai 5. Angka 1 menunjukkan level yang akan dicapai rendah dan angka 5 menunjukan level yang akan dicapai sangat tinggi.

\section{Tabel 13. Nilai Target}

\begin{tabular}{|c|l|c|}
\hline No & \multicolumn{1}{|c|}{ Technical Response } & Target \\
\hline 1 & $\begin{array}{l}\text { Pengadaan URM ditempat yang } \\
\text { strategis (tengah) }\end{array}$ & 5 \\
\hline 2 & Penambahan Perlengkapan RM & 4 \\
\hline 3 & Pelatihan Internal dan eksternal & 4 \\
\hline 4 & $\begin{array}{l}\text { Ketaatan dalam menjalankan TDF } \\
\text { ( Terminal Digit Filling ) }\end{array}$ & 5 \\
\hline 5 & Penerapan Etika Profesi & 4 \\
\hline 6 & $\begin{array}{l}\text { Kemampuan berkomunikasi } \\
\text { dengan baik }\end{array}$ & 4 \\
\hline 7 & Letak tata ruang filling & 3 \\
\hline 8 & $\begin{array}{l}\text { Memperluas ruang, pencahaya } \\
\text { dan kualitas udara yang baik }\end{array}$ & 3 \\
\hline 9 & Merevisi Protap yang ada & 5 \\
\hline
\end{tabular}

\section{KESIMPULAN DAN SARAN}

\section{Kesimpulan}

Dari analisa dapat disimpulkan bahwa untuk meningkatkan kepuasan pelanggan internal akan layanan unit rekam medis, langkah awal yaitu menitik beratkan dan memperbaiki atribut atribut dengan cara memprioritaskan keinginan pelanggan internal terhadap layanan yang diberikan oleh URM, setelah melihat dari berbagai aspek pertimbangan yang seperti terlihat ada gambar planing matrix atau penetapan target yaitu Important to customer, Customer Statisfaction Performance, Goal, Improvement ratio, Sales point, Raw weight, Normalized Raw Weight adalah

1. Letak gedung (URM) yang strategis dari rawat jalan

2. Letak gedung (URM) yang strategis dari rawat inap

3. Ruang penyimpanan yang luas

4. Perlengkapan Rekam medis

5. Jumlah pegawai

6. Sarana komunikasi

7. Kecepatan penyediaan berkas RM

8. Ketelitian dalam pengambilan berkas RM

9. Kesesuaian informasi

10. Kesiapan petugas rekam medis

11. Ketepatan dalam pengambilan berkas RM 
12. Keramahan petugas

13. Keamanan penyimpanan berkas RM

14. Sikap petugas dalam menghadapi perawat

15. Kecepatan dalam pemberian informasi dan penyediaan berkas

16. Kemudahan dalam melakukan hubungan

17. Komunikasi

\section{Saran}

1. Pada Unit Rekam Medis sebaiknya melakukan pelayanan penyediaan informasi selama 24 jam untuk menghindari adanya redudansi nomer rekam medis.

2. Sebaiknya dilakukan pelatihan secara internal dan eksternal mengenai pentingnya komunikasi yang dilakukan oleh petugas rekam medis dan perawat (maupun dokter) untuk menciptakan berkas rekam medis yang berkualitas.

3. Menentukan respon teknis sebaiknya juga di diskusikan dengan pihak manajemen rumah sakit atau komite medis rumah sakit.

4. Diperlukan adanya penelitian lebih lanjut terkait kualitas layanan unit kerja rekam medis berdasarkan kepuasan pelanggan eksternal.

\section{DAFTAR PUSTAKA}

Aji, RM .2009. Analisis Kualitas Pelayanan Medical Center Universitas Sebelas Maret Surakarta dengan Menerapkan Quality Function Deployment. Skripsi. Progam Pasca Sarjana Ekonomi, Jurusan Manajemen, Fakultas Ekonomi Universitas Sebelas Maret Surakarta.

Endang, F .2011. Pengukuran Mutu Layanan Unit Rekam Medis berdasarkan Kepuasan Perawat Rawat Inap dengan Metode Quality Function Deplyment di RSUD Waluyo Jati Kraksan. Tugas Akhir. Program D4 Rekam Medis, Jurusan Kesehatan, Politeknik Negeri Jember.
Budi, SC. 2011. Manajemen Unit Kerja Rekam Medik. Cetakan ke-1. Yogyakarta : Quantum Sinergis Media.

Hatta, GR. 2008. Pedoman Manajemen Informasi Kesehatan di Saranakan ke-12. Bandung : Pelayanan Kesehatan. Jakarta : Universitas Indonesia (UI).

Notoatmodjo, S. 2010. Metodologi Penilitian Kesehatan. Cetakan ke-1. Jakarta : Rineka Cipta.

Pohan, I S. 2007. Jaminan Mutu Layanan Kesehatan. Cetakan ke-1. ed. Jakarta: Buku Kedokteran.

Sugiyono. 2011. Metode Penilitian Kuantitatif Kualitatif dan R\&D. Cetakan : Alfabeta.

Tias, DPN. 2008. Pengukuran Kualitas Sistem Informasi Administrasi Customer Marketing Menggunakan Metode Quality Function Deployment (Stude Kasus PT. Armada Finance Jember). PUM. Program D-3 Manajemen Informatika, Jurusan Teknik Informasi, Politeknik Negeri Jember.

Goetsch, dan Davis. 2002. Pengantar Manajemen Mutu Edisi Kedua Jilid 2. Cetakan ke-2. Jakarta : PT Prenhallindo.

STjiptono, F. 2005. Prinsip - Prinsip Total Quality Service. Jakarta : C.V Andi Offset. 